\title{
A CIGÁNY NYELV HELYE A KÖZOKTATÁSBAN
}

\section{Szerzők:}

Nagygyőryné Kerti Ibolya

Debreceni Egyetem Gyermeknevelési és

Gyógypedagógiai Kar (Magyarország)

Szerző e-mail címe:

nkerti.ibolya@ped.unideb.hu
Lektorok:

Nemes Magdolna

Debreceni Egyetem (Magyarország)

Lovas Kiss Antal

Debreceni Egyetem (Magyarország)

Nagygyőryné Kerti Ibolya (2018): A cigány nyelv helye a közoktatásban. Különleges Bánásmód, IV. évf. 2018/4. szám, 73-81. DOI 10.18458/KB.2018.4.73

\begin{abstract}
Absztrakt
A magyarországi cigány népesség nemcsak társadalmi, kulturális és etnikai, hanem nyelvi szempontból is sokszínü. Az oktatás, az egészségügy, a munkaeröpiaci helyzet, és a társadalmi rétegzödés cigánysággal kapcsolatos kérdései folyamatosan a társadalomtudományi diskurzus részei. Ugyanakkor a cigány nyelv és a cigány nyelv használatának vizsgálata csak szük szakmai kör érdeklödésére tarthat számot, miközben a fokozatos nyelvcsere, a nyelvmegtartás és nyelvvesztés, vagy a nyelvpolitika kérdései különösen aktuális problémavilágot mutatnak.

Olyan nyelvröl beszélünk, amely hosszú évszázadokon keresztül fent tudott maradni az indokolatlanul eröltetett nyelvi és etnikai asszimiláció mellett. Hazánkban a nemzetiségi nevelés, oktatás formája mindig szorosan összefügg a mindenkori oktatáspolitikával. Úgy gondolom, az oktatási intézményekben minden tanuló gazdagodik egy másik nemzetiség kultúrájának, nyelvének megismerésével, amennyiben lehetösége van az iskolában tanulni azt.

A statisztikai elemzés során arra kerestük a választ, hogy kimutatható-e összefüggés a cigányság területi megoszlása és a cigány nemzetiségi oktatást folytató iskolák között.
\end{abstract}

Kulcsszavak: nemzetiségi nyelvoktatás, identitás, cigány nyelv, nyelvmegörzés

Diszciplina: pedagógia, szociológia

\section{Abstract}

THE PLACE OF THE GYPSY LANGUAGE IN PUBLIC EDUCATION

The Hungarian gypsy population is not only varied from social, cultural and ethnical side, but also from the lingual viewpoint. The education, health, the situation of the labour market and the social sciences discourses are continuously in connection with the Gypsy people. At the same time the examination of the gypsy language and the use of gypsy language can only be interest of a narrow professional circle, while the phases of gradual language changes, the language retention and loss, or the language policy issues are showing particular problems.

We are talking about a language that has been able to preserve its origins, besides the forced lingual and ethical assimilation. In our country, the form of the national upbringing and education is always really closely related to the educational policy. In my opinion, every student in the educational institutions is enriched with the knowledge of other nationalities culture and language, as they have opportunity for studying it. 
During the statistical analysis, we looking for answers to the question of whether this relationship can be traced between the territorial distribution of Roma Gypsies and the schools of Gypsy nationality education.

Keywords: national language education, identity, Gypsy language, language preservation

Disciplines: pedagogy, sociology

Jelen tanulmány célja, hogy képet adjon a magyarországi roma közösségek által beszélt cigány nyelv használatának és közoktatási helyzetének néhány jellemzőjéröl.

Magyarország legnagyobb etnikai kisebbsége a cigányság, számukra a kisebbségek jogairól szóló 1993. évi törvény deklarálja a szabad nyelvhasználat jogát. Széleskörü nyelvészeti és társadalomtudományi kutatások foglalkoznak a cigány nyelvvel és a beszélő közösségekkel (Réger 1978, Bartha 1999, Matras 1995).

A cigány nyelv eredetének első hazai felismerése Vályi István magyar lelkész nevéhez füződik, aki hollandiai tanulmányai során lett figyelmes arra, hogy indiai diáktársainak nyelve a lakóhelyén élö cigányok nyelvére nagyon hasonlít. Azóta számos kutatás igazolta be az indiai nyelvrokonság tényét. A Magyar Tudományos Akadémiai tagságot is betöltő József főherceg sokat tett a cigány nyelv tudományos igényü megismerése érdekében. Az 1950-es években Erdős Kamill kutatásaiban kategorizálta a cigány nyelvet, melynek alapján foglalkozások meghatározása mellett, a beszélt nyelvjárásokat is rögzítette. Ekkor még a cigány mesék és dalok a kárpáti dialektushoz voltak köthetők. A XX. századra tehető a cigány nyelv írásbeliségének megjelenése, ami rendkívül megkésett időpontnak tekinthető más kisebbségi nyelvekhez képest. Bari Károly gyüjtő, müfordító munkássága úttörő jelentőségü volt. Choli Daróczi József nevéhez füződik számos cigány és magyar nyelvü, a roma folklór részét képező mü megjelenése, ő írta a Zhanes Románes címü lovári nyelvkönyvet, mely az első cigány nyelvvizsgára felkészítő tananyag volt (Balogh- Fábiánné, 2015).

A nyelvhasználat jellegzetességeit és nehézségeit számos kutatás vizsgálta. Ezek közül is kiemelkedik Réger Zita munkássága, aki a szocializmus évei alatt a cigánygyerekek nyelvhasználatának nehézségeivel foglalkozott. Kiemeli a diglossziás kétnyelvüség jelentését, alkalmazását, amely a szocializációs intézményekben és az otthon beszélt nyelv különbségeire mutatott rá (Réger, 1978).

Az 1989-es rendszerváltozás előtt a cigányság erőltetett asszimilációjának kísérlete jelentősen visszavetette a cigány nyelv használatát, számos közösség nyelvvesztésen ment keresztül. Mintegy védekező stratégiaként, a többségi társadalomban való boldogulás érdekében sokan tudatosan kerülték a cigány nyelv használatát. Mindez pedig a következő generációk nyelvvesztését vonta maga után.

Sikertelenségek és kudarcok érték a magyarul nehezen beszélő cigány tanulókat. A cigány családok joggal gondolhatták azt, hogy a beolvadás nagyobb érvényesülést biztosít az oktatásban és a munkahelyeken.

Kontra Miklós a Kritika folyóiratban megjelent cikkében az alábbiak szerint kategorizálja az anyanyelveket (Kontra, 2003):

- Elsőként megtanult nyelv - származás alapján.

- Az a nyelv, amellyel a beszélő azonosul.

- A beszélö által legjobban ismert nyelv.

- A beszélö által legtöbbet használt nyelv. 
A fenti szempontok alapján egy személynek akár több anyanyelve is lehet, és életében többször változtathatja azt. Leggyakoribb, amikor anyanyelvként azt a nyelvet jelöli az adatközlő, amelyet legkorábban tanult meg.

1971 óta három nagy reprezentatív felmérés készült a magyarországi cigány népességröl (Kemény- Janky, 2003). A tanulmány a társadalmi, a gazdasági, a szociális helyzeten túl vizsgálta cigány anyanyelvü beszélők számát és arányát és annak változásait is.

1. táblázat: A magyarországi cigány népesség anyanyelvi és beszélt nyelvi megoszlására vonatkozó adatokat három szociológiai felmérésben (forrás: Kemény, 1999; KeményJanky, 2003)

\begin{tabular}{|c|c|c|c|c|c||c|c|c|c|}
\hline \multirow{2}{*}{ Év } & \multirow{2}{*}{$\begin{array}{c}\text { Becsült } \\
\text { létszám }\end{array}$} & \multicolumn{4}{|c||}{ Anyanyelv \% } & \multicolumn{3}{c|}{ Beszélt nyelv \% } \\
\cline { 3 - 9 } & & magyar & cigány & beás & egyéb & $\begin{array}{c}\text { csak } \\
\text { magyar }\end{array}$ & cigány & beás & egyéb \\
\hline 1971 & $\begin{array}{c}270000- \\
370000\end{array}$ & 71 & 21,2 & 7,6 & 0,2 & ------- & ------ & ----- & ----- \\
\hline 1993 & $\begin{array}{c}420000- \\
520000\end{array}$ & 89,5 & 4,4 & 5,5 & 0,6 & 77 & 11,1 & 11,3 & 0,6 \\
\hline 2003 & $\begin{array}{c}520000- \\
650000\end{array}$ & 86,9 & 7,7 & 4,6 & 0,8 & 74,2 & 15,4 & 7,1 & 3,3 \\
\hline
\end{tabular}

A szociológiai vizsgálat adatainak (1. táblázat) alapján jól látható, hogy a magyarországi cigányok három nagy nyelvi csoportja közül a romungrók csak magyarul beszélnek. Ezen kívül vannak a magyarul és cigányul beszélő oláh cigányok, akik a lovári nyelvet és annak dialektusait beszélik. A harmadik csoportot alkotják a magyarul és románul beszélő cigányok, akik magukat beásnak mondják. Kemény adatai azt mutatják, hogy a lovári nyelven beszélő cigányok száma 21, 2 százalékról 4,4 százalékra csökkent. A beás nyelven beszélő cigányok száma 7,6 százalékról 5,5 százalékra csökkent. Míg a magyarul beszélök száma 71 százalékról 89,5 százalékra emelkedett. Huszonkét év alatt a magyarországi cigány népesség a táblázat szerinti adatok mértékében nyelvileg asszimilálódott. Az 1970-es években még a szakmai és nyelvészeti diskurzusokban is helyet adtak annak a cigány nyelvi elöítéleteken alapuló ideológiának, miszerint a cigány nyelveknek szük szókincse van, és a nyelv társadalmi megítélése igen alacsony presztízsü. Viszont arról nem született vélemény, hogy a cigány nyelveket kizárták az intézményi színtérről és így elsősorban a szóbeli kommunikáció vált erőteljessé a roma közösségekben.

Egy országban a nyelvhasználat lehetőségei mindig visszahatnak a nyelvi korpuszra, ha például az oktatásban nem használják a kisebbségi nyelvet, akkor a nyelvhasználatához, tanulásához szükséges taneszközök sem fejlődnek. Hazánkban a cigány nemzetiségi oktatás a kezdetektől nehéz helyzetben van. A nemzetiségi nevelés-oktatás célja elsősorban a cigány nemzetiségi hagyományok megismerésére, a nyelv ápolása, megőrzése valamint annak tovább örökítése. Több kérdés is felmerül a nemzetiségi oktatással kapcsolatban. Kinek szóljon? Vegyen-e részt rajta minden diák vagy csak a cigány származású tanulók? Rendelkezésre állnak-e az oktatás tárgyi és személyi feltételei? Mivel a nemzetiségi oktatás óraszám emelkedéssel jár, terhelhetők-e ezzel még tovább az egyébként is leterhelt diákok és pedagógusok, mivel a nemzetiségi oktatás vállalása plusz óraszám emelkedéssel jár együtt.

A cigánysággal való együttmüködés érdekében elengedhetetlen a kultúrájukkal, hagyományaikkal való megismerkedés. Kultúrájuknak nagyon fontos eleme a zene, többen a nyelvet is a cigány szövegü dalok révén sajátítják el, ezáltal is erösödik az összetartozás tudat, a csoport kohézió. 
Hazánkban a nemzetiségi nevelés a cigány nyelv oktatása megjelenése és formája szorosan összefügg a mindenkori nemzetiségi és oktatáspolitikával. Az 1989-es rendszerváltás előtt és után is többször változtak az oktatást szabályozó törvények, de a módosítások egyike sem hozott számottevő változást. Magyarországon az 1993 évi közoktatási törvény deklarálja, hogy minden hazánkban élő nemzetiségnek joga van a nemzetiségi és nyelvi oktatáshoz.

Hazánkban a nemzetiségek megoszlását a 2011-es népszámlálási adatok alapján a következő ábra reprezentálja (1. ábra).

1. ábra: Nemzetiségek megoszlása, 2011 (forrás: KSH 2011. évi népszámlálások 9. nemzetiségi adatok alapján a szerzö saját szerkesztése)

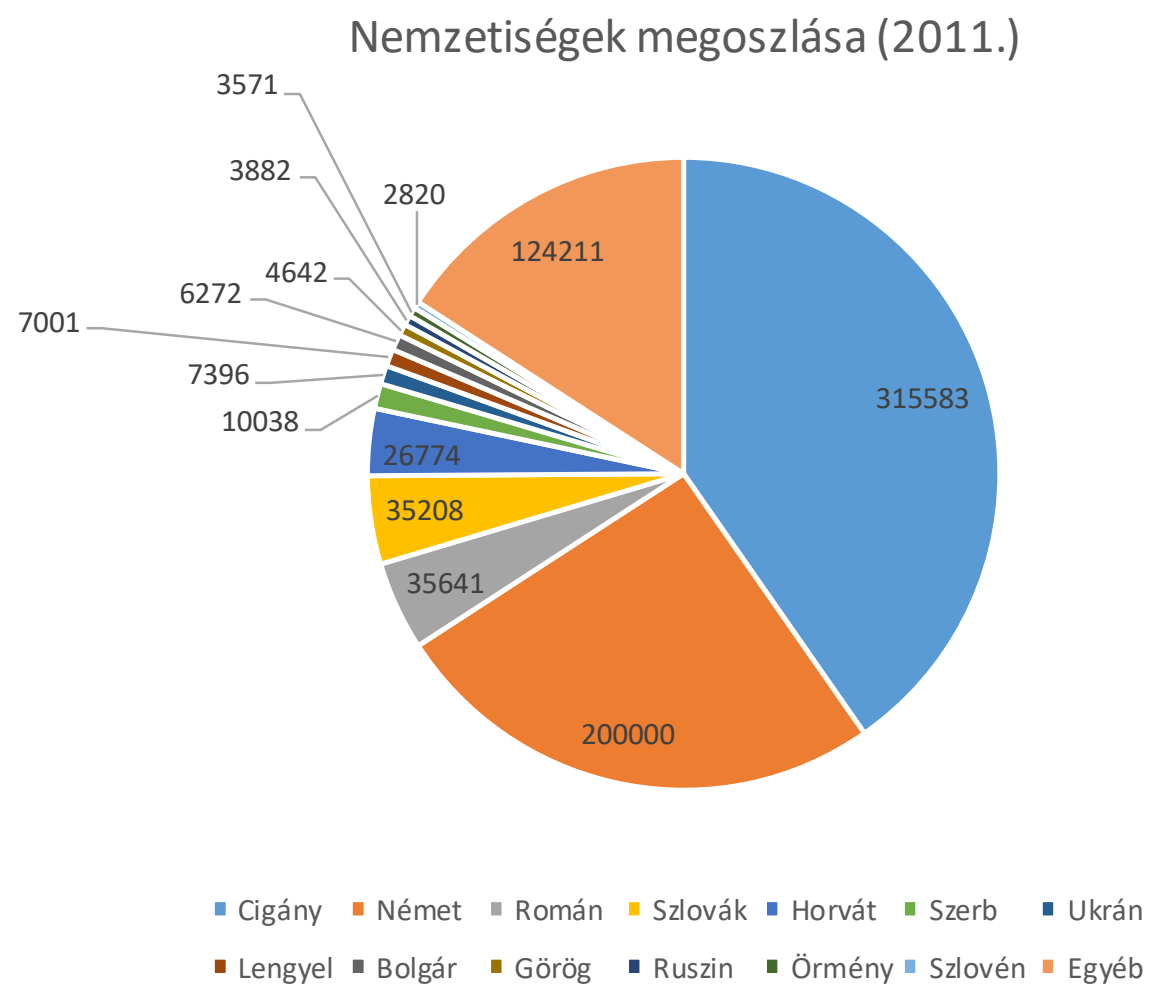

A KSH adatai a 2011-es népszámlálás adatait veszi alapul a hazánkban élő nemzetiségek megoszlásának bemutatására. A szociológiai felmérések adatai szerint a romák becsült száma már 2013-ben is több volt, mint 876.000 (Pénzes- Tátrai- Pásztor, 2018).

$\mathrm{Az}$ adatok alapján érdemes áttekinteni, hogy Magyarország mely régióiban, megyéiben vannak olyan közoktatási intézmények, amelyek cigány nemzetiségi oktatást folytatnak. Feltételezésem az volt, hogy összefüggés van a nemzetiségi iskolák száma és azon települések között, ahol a romák lélekszáma igen magas. Úgy gondoltuk, hogy azokban a megyékben, ahol magas a cigány lakosok száma ott a cigány nemzetiségi programokat alkalmazó közoktatási intézmények száma is magas lesz. A bizonyításhoz demográfiai és statisztikai adatokat vetettük össze. Köztudott, hogy a népszámlásokon magukat cigánynak valók száma nagymértékben elmarad a vélt cigány népesség számától. Ennek egyik oka az lehet, hogy a legtöbb cigány már csak magyarul beszél, tehát magyar anyaanyanyelvünek tartja magát. A másik oka talán az lehet, hogy nagyon heterogén csoportról van szó. 
2. ábra: A roma népesség száma Magyarországon 1893 és 2013 között (forrás: Pénzes János, Tátrai Patrik és Pásztor Zoltán: A roma népesség területi megoszlásának változása Magyarországon az elmúlt évtizedekben, 2018 9.)

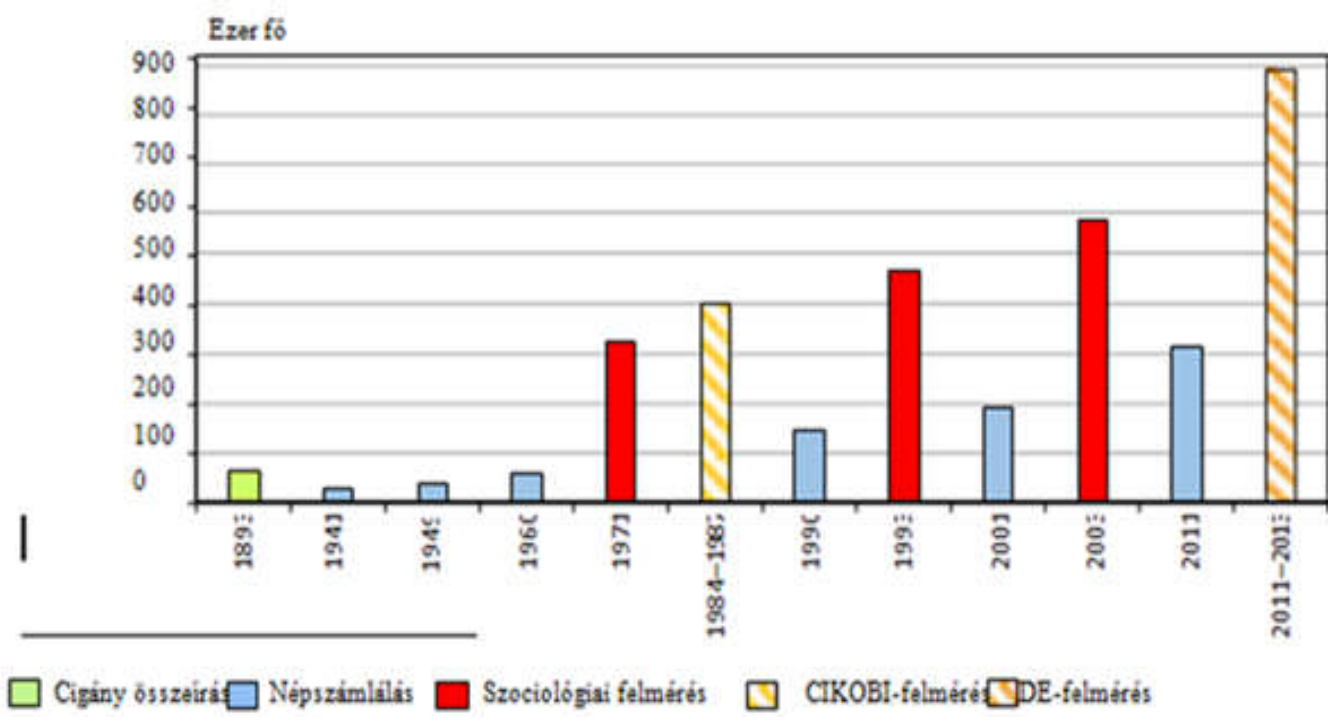

Az 1893-as években 65 ezer cigányról számoltak be, a 2003. évi felmérés alapján 570 ezer főről, a 2011-es népszámlálás adatai 316 föt mutatnak. Míg a Debreceni Egyetem kutatása alapján 2010 és 2013 között több mint 876 ezerre becsülték a cigányság számát (PénzesTátrai- Pásztor, 2018).

Mivel arra kerestük a választ, hogy kimutatható-e összefüggés a cigányság területi megoszlása és a cigány nemzetiségi oktatást folytató iskolák között, így a megyékre lebontott adatok megfigyelésére is szükség van.

Az alább látható 3. ábra különböző adatbázisok adatait használja fel és veti össze. Mind a szociológiai felmérések mind a népszámlálások és a CIKOBI (Cigány Koordinációs Bizottság) és a Debreceni Egyetem 2010-13 évi felméréseink eredményei megjelennek rajta.

3. ábra A roma népesség száma Magyarországon különbözö adatbázisok alapján (forrás: Pénzes János, Tátrai Patrik és Pásztor Zoltán: A roma népesség területi megoszlásának változása Magyarországon az elmúlt évtizedekben, 2018 10. o.)

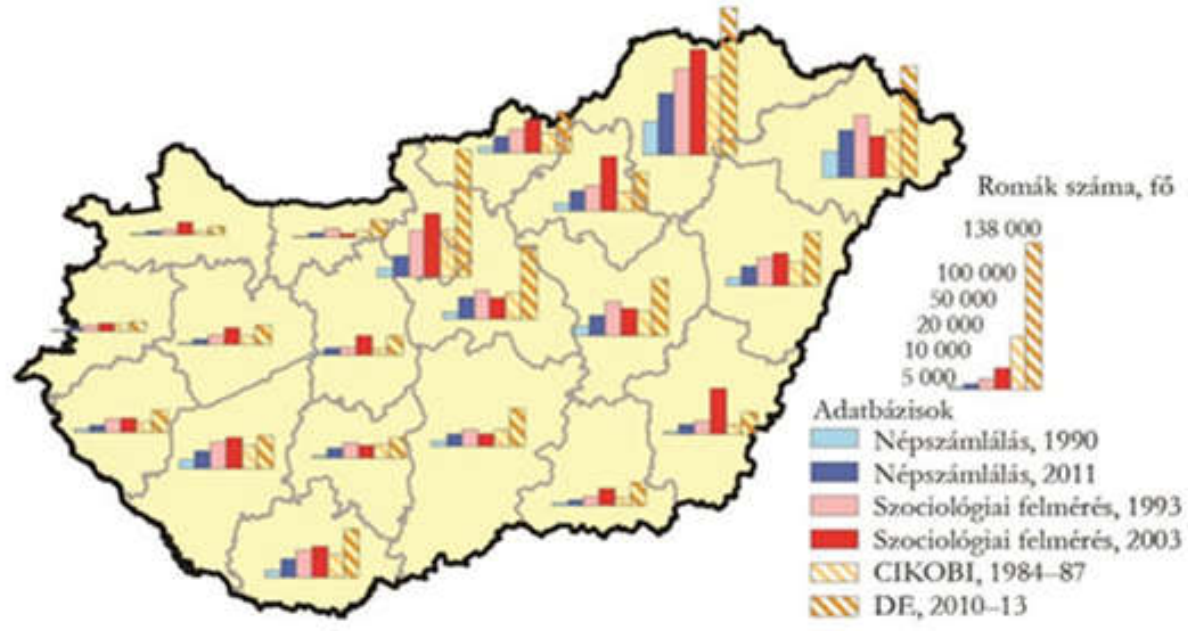


A térkép adatai azt mutatják, hogy magas a roma lakosság aránya Borsod-Abaúj-Zemplén megyében, Szabolcs-Szatmár-Bereg megyében, Hajdú-Bihar megyében és Baranya megyében. Alacsonyabb a romák lakta települések száma Vas megyében, Veszprém megyében, Zala megyében, Komárom-Esztergom megyében és Fejér megyében.

A Magyar Tudományos Akadémia Kisebbségkutató Intézetének igazgatója Papp Z. Attila 2015-ben végzett kutatást az iskolák által közölt becslések alapján a cigány tanulók megoszlásának adataival kapcsolatosan. A kisebbségkutató azokat a számokat használta fel, amelyek az iskolákban az országos kompetenciamérés során keletkeztek. Ezeken az adatlapokon ugyanis a pedagógusoknak meg kell becsülni a hozzájuk járó roma diákok arányát. A kutatás eredménye, hogy a cigány tanulók aránya az általános iskolákban átlagosan meghaladta országosan a $15 \%$-ot, de a megyék között nagyon nagy eltérések mutatkoznak. Míg Borsodban ez az arány 34,3\%, addig Győr-Moson-Sopron megyében ez a szám 4,2 \%. Észak-Magyarországon vannak olyan iskolák, ahol szinte $90 \%$-os a roma tanulók aránya (Net1, 4. ábra).

\section{4. ábra. A roma általános iskolai tanulók becsült aránya megyénként.} (forrás:www.mandiner.hu)

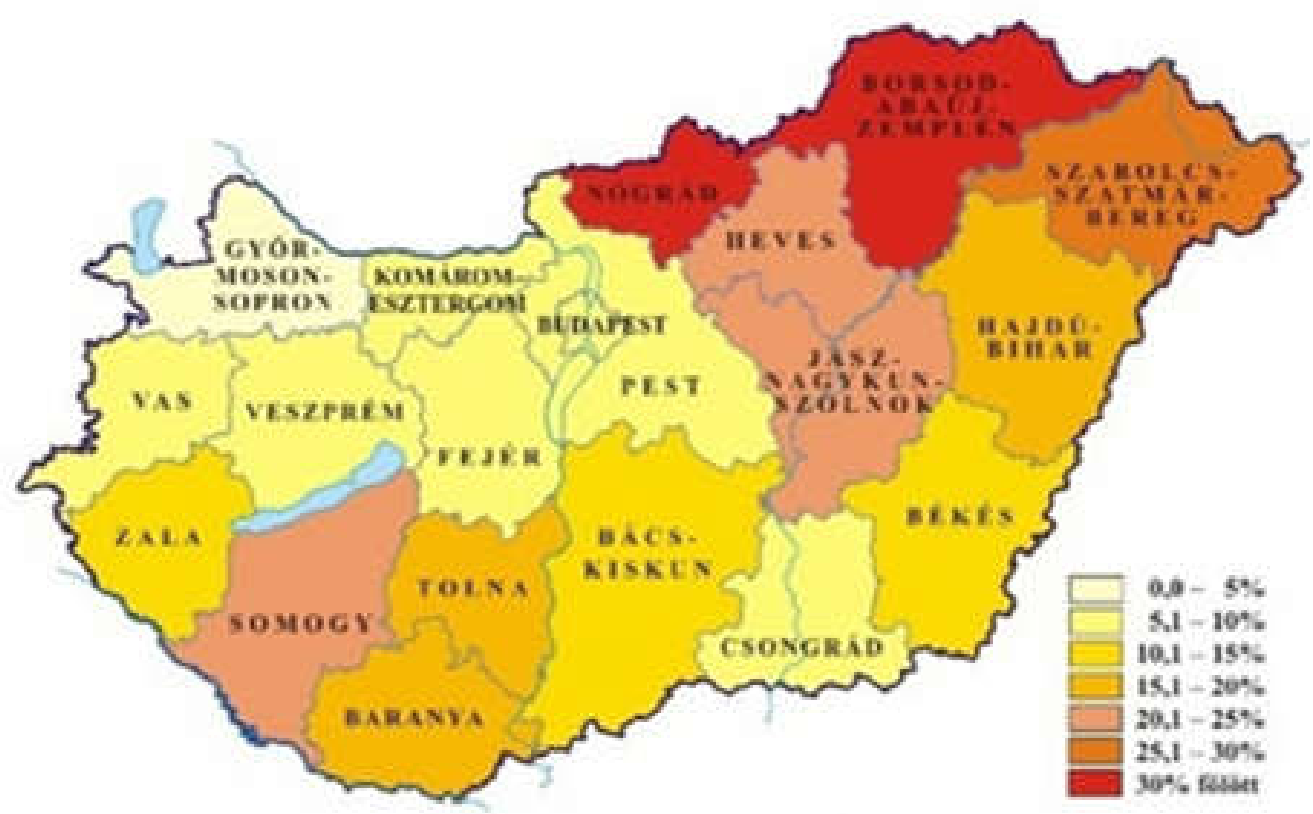

A nemzetiségi intézménylista a 2017-évi Köznevelési Információs Rendszer (KIR) adatai alapján 36 olyan közoktatási intézményt jelöl, ahol lehetőség van cigány nemzetiségi nevelésoktatás valamelyik formájára. 
5.ábra. Cigány nemzetiségi nevelés - oktatást folytató intézmények Magyarországon 2017-ben (forrás: KIR/Közérdekü adatok/ Nemzetiségi nevelésben, oktatásban részt vevö köznevelési intézmények elérhetöségei, tanulóik létszáma alapján a szerzö saját szerkesztése)

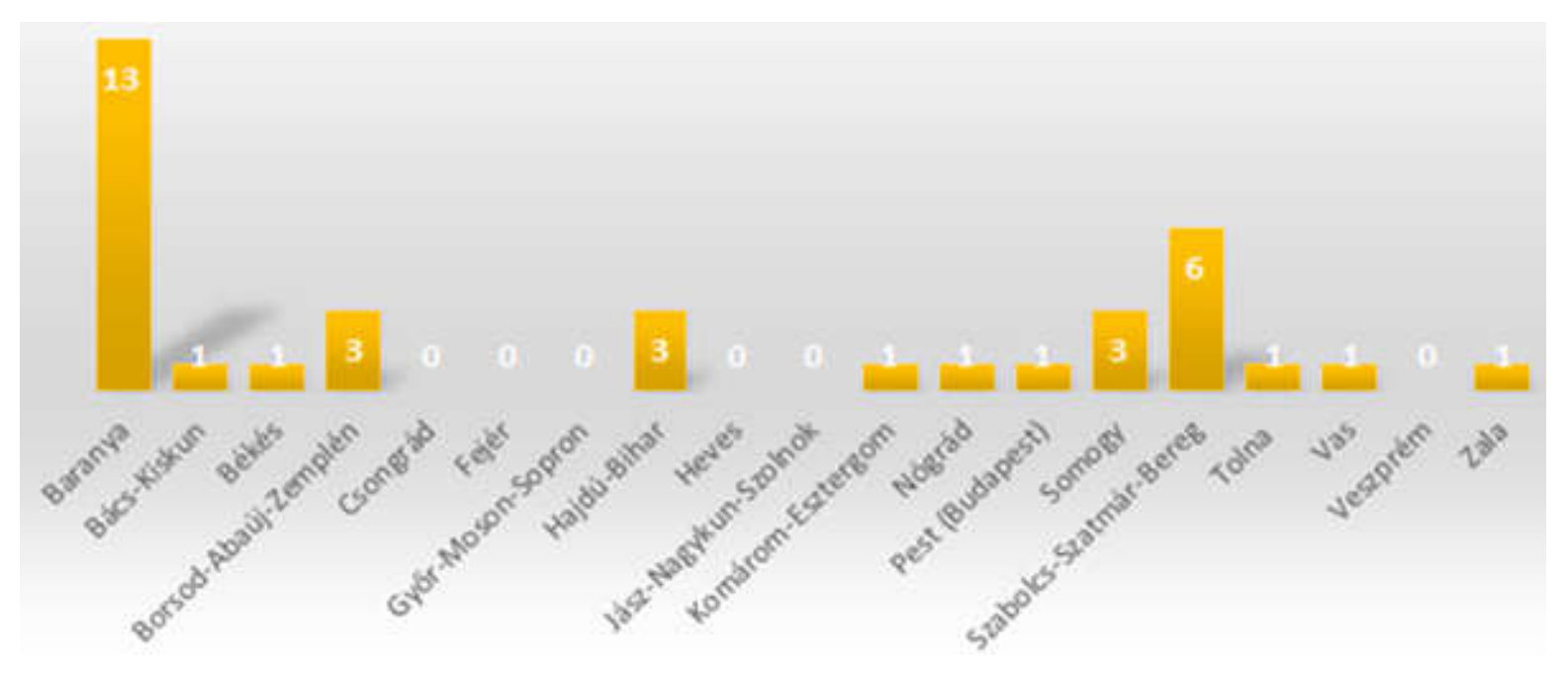

Az 5. ábrából megállapítható, hogy Borsod megyében, ahol az össznépesség számának 13,3\%-a roma, ott mindösszesen három intézményben, Múcsonyban, Pálházán és Sátoraljaújhelyen folyik nemzetiségi oktatás. Baranya megyében, ahol a roma népesség aránya $7,1 \%$, az alacsony érték ellenére itt van a legtöbb cigány nemzetiségi oktatást folyató intézmény. Baranya megyében található cigány nevelés-oktatást végző intézmények települések szerinti megoszlása: Pellérd, Egyházasharaszti, Sellyén 2 intézmény, Szalánta, Szigetvár, Pécs, Komló 3db iskola, Szentlőrinc, Alsószentmárton, Mohács.

Bács-Kiskun megyében Kecel településen annak ellenére van roma kétnyelvü oktatás az óvodában, hogy az összlakosságnak mindösszesen csak a 2\% cigány származású. Csongrád, Fejér, Győr-Moson-Sopron és Veszprém megyében nincs cigány nemzetiségi nevelés-oktatást folytató intézmény, a demográfiai adatok tükrében ez érthető is. Vas megyében viszont a cigány lakosok száma 1,8 százalék mégis van egy iskola Szentgotthárdon, amely cigány nemzetiségi programban vesz részt.

Amennyiben a gyermek/tanuló törvényes képviselöje hivatalosan kéri, úgy az intézmény fenntartó köteles biztosítani a cigány nyelv oktatását is. A 17/2013.(III.1.) EMMI rendelet a nemzetiségi óvodai nevelésnek irányelve és a nemzetiség iskolai oktatásának irányelve értelmében ugyanazon nemzetiséghez tartozó szülök indítványozhatják a nemzetiségi oktatás bevezetésére irányuló igényüket. Legalább nyolc fö cigány származású szülő kérelme szükséges és legalább nyolc fö cigány nemzetiségü gyermeknek be is kell iratkozni az iskolába, ahhoz hogy ez megvalósulhasson.

A 2011. évi CLXXIX törvény meghatározza a nemzetiségek jogait, kitér a kisebbségi nyelvek oktatási jogaira is. Ez a törvény által biztosított jog azért is kiemelten fontos, mert megakadályozhatja a nyelvvesztést. Nyelvi szempontból minden kisebbségi kétnyelvü közösség veszélyeztetett, amelyben eredeti nyelvüket a nagyszülök, szülök már nem adják át a fiatalabb generációnak (Bartha, 1999).

A nyelvi diglosszia jelentése Fishman (Fishhman, 1967) meghatározása szerint az, hogy egy nyelvnek van egy közönséges és egy emelkedett nyelvi változata is. Az emelkedett nyelvi 
változatokat elsősorban az oktatási intézményekben sajátítják el a gyerekek. Fishman (Fishhmann, 1967) meghatározása szerint a kisebbség nyelve a közönséges nyelvi változat, a többségi társadalomé pedig az emelkedett, mely a formális színtereken valósul meg.

A cigányság nyelve visszaszorult, beszélői leginkább informális tereken tudják használni a nyelvet, otthon családi körben.

A nyelvcsere folyamata már évtizedekkel ezelőtt elindult, mert az oktatás és az intézményi kommunikáció ezt kívánta meg. A nyelvcsere az a folyamat, amelynek során két hosszú ideig egymással érintkező vagy szomszédságban élő közösség közül az egyik a saját nyelvét fokozatosan feladva átveszi a mellette élő közösség nyelvét (Bartha, 1999). A nyelvcsere a magyarul beszélő romungró cigányok esetében már véglegesnek tünik. A fokozatos nyelvcsere fázisai:

- elkerülhetetlen a nyelvi érintkezés egy másik nyelvi csoporttal,

- megjelenik a kétnyelvüség,

- az eredeti nyelv használata visszaszorul informális szintre,

- a beszélők egyre szélesebb körét érinti a kétnyelvüség, amely végül egynyelvüséghez fog vezetni (Bartha, 1999).

A beás és a lovári nyelvet beszélök között még vannak úgy nevezett „nyelvszigetek”, ahol élnek nyelvet beszélő közösségek. A szociolingvisztikai szempontból a nyelvcsere végleges megtörténéséhez legalább három generáció kell, aki már nem beszéli a nyelvet. Bár még az idős generációk tagjai közül többen beszélik a lovari nyelvet, a fiatal generációk számára már nem jelent sem előnyt, sem pragmatikus célt a nyelv elsajátítása, ezért nem tanulják meg.

\section{Összegzés}

Az adatok tükrében nem helytálló az a feltételezés, hogy összefüggés lenne a cigányság sürün lakta településeinek lélekszáma és cigány nemzetiségi oktatást folytató intézmények száma között.

A közoktatási intézmények saját mérlegelésük vagy szülői kérelmek alapján dönthetik el a kétnyelvü nemzetiségi oktatás bevezetését intézményeikben. A jogszabályi feltételek rendelkezésre állnak. A cigányok részéről a cigány nyelv elsajátítása, használata saját döntések elvén müködhet. Ma Magyarországon akkreditált nyelvvizsgát lehet tenni lovári és beás nyelvekből is.

A nyelv ismerete/használata, az identitás erősítését segítő egyik tényező. Amennyiben egy cigány diák vagy föiskolai hallgató találkozik a többségi társadalom által elfogadott terekben, intézményekben, iskolákban, médiában a cigány nyelvvel, amit esetleg a szülei, nagyszülei még beszélnek, az mindig pozitív értéket hordoz magában. Ha nem találkozik, ősei nyelvével a tanulmányai során annál nagyobb lehet az aggodalma, hogy cigánysága hátrányt jelenthet számára. Ez az aggodalom kultúraváltáshoz és a nyelv elhagyásához vezethet, erre mutat rá Forray és Orsós tanulmánya is (Forray - Orsós, 2016).

A kisebbségi nyelv beszélöinek nyelvhasználatában az a racionális gazdasági megfontolás mutatkozik, hogy előnyt jelent-e a diploma megszerzésében az otthonról hozott nyelv vagy sem. Sok fiatal nem használja szívesen a cigány nyelvet házon kívül, csak saját rokonaival beszél otthon családi környezetben.

A tapasztalatok, mint cigány/lovári nyelvbeszélő azt mutatják, hogy az idősebb cigány származású emberek kifejezetten örülnek annak, ha a fiatalok részéről, vagy akár idegenek részéröl is cigányul beszélővel találkoznak.

Nyelvmegtartás, illetve nyelvújítás támogató programok megtervezéséhez elengedhetetlen a lokális közösségekre fókuszáló kutatások elvégzése. A támogató nyelvpolitikai intézkedések és a kisebbség nyelvén történő anyanyelvi oktatás alappillére lehet a nyelvmegőrzésének. 


\section{Irodalomjegyzék}

17/2013. (III.1.) EMMI rendelet

2011. évi CLXXIX. törvény a nemzetiségek jogairól

Andl, H. (2015. nyár). A Kisiskolák és nemzetiségi oktatás összefüggésrendszerének néhány aspektusáról. Romológia folyóirat. III. évfolyam, 9. szám.

Bartha, CS. (1999). Kétnyelvüség, nyelvcsere: a kisebbségi nyelvek megörzésének lehetöségei. Budapest: ELTE BTK Mai Magyar Nyelvi Tanszék, MTA Kisebbségkutató Intézet.

Erdős, K. (1989). Cigány lókereskedők Magyarországon. In Vekerdi József (szerk.): Erdős Kamill cigánytanulmányai. Békéscsaba: Gyulai Erkel Ferenc Múzeum Kiadványai 89-92.

Fábiánné Andrónyi, K., \& Balogh, Z. ( 2015). Romológiai ismeretek. 97-98 o.

Fishman, J. (1967): Bilingualism with and without Diglossia, Diglossia with and without Bilinguaslim. The Journal of Social Issues 2. 29-38.

Forray R. K., \& Orsós A. (2016). Roma jövő Magyarországon. Educatio 25. évf., 4. sz., Budapest.

Kemény, I., \& Janky, B. (2003). A cigány kisebbségi adatokról. Kisebbségkutatás 12 (2)309-3015.

Kontra, M. (2003). Cigányaink, nyelveik és jogaik. Kritika. 24-26.

KSH 2011. évi népszámlálás 9. nemzetiségi adatok.

Matras, Y.(1995). Romani in Contact. The, History, structure and socology of a Langauage. Jonh Benjamins, Amsterdam.

Pénzes, J., Tátrai, P., \& Pásztor, I. Z. (2018): A roma népesség területi megoszlásának változása Magyarországon az elmúlt évtizedekben. Budapest.

Réger, Z. (1978). Cigányosztály, „vegyes” osztály - a tények tükrében. Valóság, 8, 77-89.

Szalai, A. (2015) . A cigány kisebbség nyelvei: szociolingvisztikai aspektusok. In: $A$ romológia alapjai. Pécsi Tudámányegyetem BTK Neveléstudományi Intézet, Romológia és Nevelésszociológia Tanszék., Pécs, 117-150.

Net1:http://mandiner.hu/cikk/20150420_roma_diak_arany_magyarorszagon_papp_z_attila_in terju (Letöltés: 2018.10.01) 